$\begin{array}{rr}\text { JURNAL } & \text { Volume } 13, \text { Nomor 6, November } 2017 \\ \text { FIT(1)PATOLOGI } & \text { Halaman 229-237 } \\ \text { I N D ON E S I } & \text { DOI: } 10.14692 / \text { jfi. } 13.6 .229 \\ \text { ISSN: } 0215-7950 & \end{array}$

\title{
Kisaran Inang Cowpea mild mottle virus dan Respons Varietas Kedelai
}

\section{Host Range of Cowpea mild mottle virus and Response of Soybean Varieties}

\author{
Mimi Sutrawati, Sri Hendrastuti Hidayat*, Bonny Purnomo Wahyu Soekarno, \\ Ali Nurmansyah, Gede Suastika \\ Institut Pertanian Bogor 16680
}

\begin{abstract}
ABSTRAK
Cowpea mild mottle virus (CPMMV) merupakan salah satu virus yang menginfeksi kedelai dan menjadi penyakit endemik di Jawa dan Sumatera sejak pertama kali dilaporkan. Penelitian bertujuan menguji kisaran inang CPMMV dan mengevaluasi respons varietas kedelai baru terhadap isolat spesifik CPMMV. Pengujian kisaran inang CPMMV isolat CR16 dilakukan dengan cara menularkan virus secara mekanis pada11 spesies tanaman indikator, sedangkan tanaman kedelai yang dievaluasi terdiri atas 10 varietas. Respons ketahanan varietas kedelai ditentukan berdasarkan pada periode inkubasi, insidensi dan keparahan penyakit. Infeksi CPMMV pada tanaman uji dikonfirmasi dengan metode dot immunobinding assay (DIBA) menggunakan antiserum spesifik CPMMV. CPMMV isolat CR16 mampu menginfeksi 8 spesies tanaman Leguminoseae, dan Solanaceae secara sistemik; sedangkan pada Amaranthaceae hanya secara lokal. Semua tanaman indikator yang menunjukkan gejala sistemik dapat menjadi sumber inokulum CPMMV saat diinokulasi kembali pada tanaman kedelai. Kedelai varietas 'Detam 1', 'Detam 2', 'Detam 3', 'Anjasmoro', dan 'Wilis' tergolong rentan; sedangkan varietas 'Detam 4', 'Malika' dan 'Dena 1' tergolong moderat; serta varietas 'Argomulyo' dan 'Grobogan' tergolong tahan terhadap infeksi CPMMV isolat CR16.
\end{abstract}

Kata kunci : dot immunobinding assays, sistemik, sumber inokulum, tanaman indikator

\section{ABSTRACT}

Cowpea mild mottle virus (CPMMV) is one of important virus which infects soybean and become an endemic disease since the first time reported in Java and Sumatra. Research was conducted to study the host range of CPMMV and to evaluate response of new type soybean varieties to CPMMV specific isolate. Host range study of CPMMV CR16 isolate was conducted by sap transmission method to 11 species of indicator plants, whereas evaluation of soybean response involved 10 varieties. The resistance response of soybean variety was based on incubation period, and of either the disease incidence or severity. Virus infection on test plants were confirmed by dot immunobinding assay (DIBA) using specific CPMMV antisera. The CPMMV CR16 isolate was able to infect systemically 8 plant species belongs to Leguminoceae, and Solancaeae; while the virus caused local infection on Amaranthaceae. All plant species infected systemically proved to become sources of inoculum for CPMMV when they used in back inoculation to soybean. Response of soybean varieties to CPMMV CR16 isolate can be categorized into susceptible (Detam 1, Detam 2, Detam 3, Anjasmoro, Wilis), moderated (Detam 4, Malika, Dena 1) and resistant (Argomulyo and Grobogan).

Key words: dot immunobinding assays, indicator plant, source of inoculum, systemic

*Alamat Penulis Korespondensi: Departemen Proteksi Tanaman, Fakultas Pertanian, Institut Pertanian Bogor. Jalan Kamper, Kampus IPB Dramaga, Bogor 16680.

Tel: 0251629364, Faks: 0251629362, Surel: srihendrastutihidayat@gmail.com. 


\section{PENDAHULUAN}

Cowpea mild mottle virus (CPMMV) yang tergolong dalam genus Carlavirus, famili Betaflexiviridae dapat ditularkan secara mekanis dan diduga bersifat tular benih. Berbeda dengan Carlavirus lainnya yang ditularkan oleh kutudaun, CPMMV ditularkan oleh Bemisia tabaci (Hemiptera: Aleyrodidae) secara nonpersisten (Jeyanandarajah dan Brunt (2008). Penyakit belang pada tanaman kedelai yang disebabkan oleh CPMMV pertama kali dilaporkan di Jawa dan Sumatera pada tahun 1984 (Iwaki et al. 1986). Gejala infeksi CPMMV ialah belang sistemik, pemucatan tulang daun, dan distorsi daun pada tanaman kedelai. Infeksi CPMMV menyebabkan penurunan bobot kering berangkasan tanaman kedelai hingga $15.5-53.4 \%$, penurunan bobot biji kedelai $11.5-51.6 \%$, dan penurunan kualitas biji 7.6-54.4\% (Akin 2003).

Peneliti di berbagai negara melaporkan adanya perbedaan kisaran inang dan keragaman gejala infeksi CPMMV pada tanaman inang berbeda. Virus ini terdeteksi pada tanaman Solanaceae, yaitu Solanum melongena di Yordania dan Israel, tetapi isolat CPMMV tersebut tidak sama dengan isolat CPMMV yang menginfeksi Leguminosae (Mansour et al. 2008). Insidensi CPMMV pada tanaman kacang panjang berkisar $15-40 \%$ di Venezuela (Brito et al. (2012). Infeksi alami CPMMV pada kacang panjang dan kacang buncis juga dilaporkan di Taiwan (Chang et al. 2013). Hal tersebut menunjukkan infeksi CPMMV terus meluas pada berbagai tanaman inang di berbagai negara. Di Indonesia, selain pada kedelai infeksi CPMMV belum pernah dilaporkan.

Evaluasi ketahanan varietas kedelai yang dilakukan oleh Akin (2003) menunjukkan bahwa infeksi CPMMV dapat menurunkan bobot berangkasan tanaman dan bobot biji, serta meningkatkan jumlah biji tidak normal. Ia menyimpulkan kedelai varietas Taichung tergolong rentan dan galur B 3570 tergolong toleran terhadap infeksi CPMMV. Pengembangan varietas kedelai dengan perbaikan genetika terus dilakukan untuk mendapatkan varietas unggul berdaya hasil tinggi, tetapi belum ada informasi respons ketahanan varietas terhadap infeksi CPMMV. Penelitian ini bertujuan menguji kisaran inang CPMMV dan respons ketahanan beberapa varietas kedelai terhadap infeksi CPMMV isolat CR16.

\section{BAHAN DAN METODE}

\section{Pemurnian dan Propagasi Inokulum Isolat CR 16}

Isolat CPMMV yang digunakan ialah isolat CR16 yang berasal dari daerah Ciranjang, Cianjur, Jawa Barat. Isolat tersebut dimurnikan terlebih dahulu sebelum digunakan sebagai sumber inokulum. Daun kedelai yang terinfeksi CPMMV isolat CR16 digerus dalam bufer fosfat $0.1 \mathrm{M} \mathrm{pH} 7.0$ (1:5 $\mathrm{b} / \mathrm{v}$ ) sehingga diperoleh ekstrak tanaman sakit (sap). Daun primer tanaman kedelai ditaburi carborundum 600 mesh dan selanjutnya sap dioleskan pada daun tersebut. Tanaman yang telah diinokulasi dipelihara dalam kurungan kedap serangga. Tanaman yang menunjukkan gejala khas terinfeksi CPMMV berupa belang sistemik dan deformasi daun dideteksi dengan antiserum CPMMV dan CMV untuk memastikan infeksi tunggal CPMMV.

Pemurnian tahap ke-2 dilakukan menggunakan serangga vektor. Kutukebul sebanyak 10 ekor diletakkan pada tanaman kedelai sumber inokulum selama 24 jam untuk periode makan akuisisi. Satu hari kemudian, kutukebul dipindahkan ke tanaman kedelai sehat selama 48 jam untuk menularkan CPMMV. Tanaman dipelihara di dalam kurungan kedap serangga sampai muncul gejala. Konfirmasi infeksi CPMMV pada tanaman kedelai yang bergejala belang sistemik dan deformasi daun dilakukan pada 7 hari setelah inokulasi (HSI) dengan metode DAS-ELISA (Clark dan Adams (1977). Propagasi virus dilakukan pada tanaman kedelai varietas Wilis melalui penularan secara mekanis mengikuti metode yang diuraikan sebelumnya. 


\section{Pengujian Kisaran Inang}

Pengujian kisaran inang CPMMV dilakukan pada 11 spesies tanaman dari famili Leguminosae (Vigna unguiculata subsp. sesquipedalis, V. radiata, Phaseolus vulgaris, Arachis hypogaea, dan Glycine max), Solanaceae (Lycopersicum esculentum, Solanum melongena, Nicotiana tabacum, dan $N$. benthamiana), Chenopodiaceae (Chenopodium amaranticolor), dan Amaranthaceae (Gomphrena globosa). Tanaman uji tersebut selanjutnya disebut tanaman indikator.

Percobaan disusun dalam rancangan acak kelompok dengan perlakuan 11 spesies tanaman indikator, masing-masing diulang sebanyak 10 tanaman. Inokulasi CPMMV dilakukan secara mekanis seperti yang telah diuraikan sebelumnya. Tanaman kontrol ialah tanaman yang diinokulasi hanya dengan bufer fosfat. Pengamatan meliputi tipe gejala dan masa inkubasi. Infeksi CPMMV dikonfirmasi secara serologi dengan metode Dot Immunobinding Assays (DIBA) pada 2 minggu setelah inokulasi (MSI).

Inokulasi balik CPMMV ke tanaman kedelai. Pengujian ini dilakukan untuk mengetahui potensi tanaman yang digunakan pada pengujian kisaran inang sebagai sumber inokulum CPMMV bagi tanaman kedelai. Tanaman indikator yang menunjukkan gejala sistemik dan dideteksi positif terinfeksi CPMMV digunakan sebagai sumber inokulum untuk penularan ke tanaman kedelai sehat menggunakan metode penularan mekanis seperti yang diuraikan sebelumnya. Gejala penyakit dan periode inkubasi diamati hingga 1 minggu setelah tanam (MST). Infeksi CPMMV dikonfirmasi secara serologi dengan metode DIBA.

\section{Evaluasi Respons Varietas Kedelai terhadap Infeksi CPMMV}

Varietas kedelai yang diuji terdiri atas 5 varietas kedelai kuning (Anjasmoro, Wilis, Argomulyo, Grobogan, Dena 1) dan 5 varietas kedelai hitam (Detam 1, Detam 2, Detam 3, Detam 4, Malika).
Penelitian disusun dalam rancangan acak kelompok dengan perlakuan 10 varietas kedelai, setiap perlakuan diulang 5 kali, masing-masing ulangan terdiri atas 4 tanaman. Benih kedelai ditanam pada medium campuran tanah, sekam, dan kompos dengan perbandingan $2: 1: 1(\mathrm{~b} / \mathrm{b} / \mathrm{b})$ di dalam pot plastik berukuran $30 \mathrm{~cm} \times 30 \mathrm{~cm}$ dan dipelihara di rumah kasa.

Inokulasi CPMMV dilakukan secara mekanis pada daun tunggal tanaman kedelai berumur 7 hari setelah semai (HSS) mengikuti metode yang telah diuraikan sebelumnya. Peubah yang diamati meliputi tipe gejala, masa inkubasi, insidensi dan keparahan penyakit. Deteksi CPMMV dilakukan dengan metode DIBA pada 2 MSI. Insidensi dan keparahan penyakit dihitung dengan rumus:

$$
\mathrm{IP}=\frac{\mathrm{n}}{\mathrm{N}} \times 100 \% \text {, dengan }
$$

IP, insidensi penyakit (\%); n, jumlah tanaman terinfeksi CPMMV (berdasarkan hasil DIBA); $\mathrm{N}$, total jumlah tanaman yang diamati.

$$
\mathrm{KP}=\frac{\sum_{\mathrm{i}=0}^{i}\left(\mathrm{n}_{i} \times \mathrm{v}_{i}\right)}{\mathrm{N} \times \mathrm{V}^{*}} 100 \% \text {, dengan }
$$

$\mathrm{KP}$, keparahan penyakit (\%); $\mathrm{n}$, jumlah sampel untuk kategori serangan tertentu; v, nilai skor untuk kategori serangan tertentu; $Z$, nilai skor tertinggi; $N$, jumlah sampel untuk skor tertinggi.

Penentuan skor gejala penyakit CPMMV pada kedelai mengikuti Akin (2003), yaitu 0, tidak ada gejala; 1, klorosis dan tulang daun memucat; 2, gejala mosaik dengan klorosis pada tulang daun dan permukaan daun; 3, mosaik berat, permukaan daun bergelombang, tepi daun melengkung ke atas; 4 , malformasi daun (Gambar 1). Selanjutnya dibuat matriks skoring yang meliputi periode inkubasi (HSI), insidensi penyakit (\%), dan keparahan penyakit (\%) (Tabel 1).

Ketahanan varietas kedelai terhadap CPMMV ditentukan berdasarkan lama periode inkubasi (HSI), insidensi penyakit (\%) dan keparahan penyakit (\%) dikelompokkan sebagai berikut: tahan (total skor 3-4), moderat (total skor 6-9), dan rentan (total skor 10-12). 


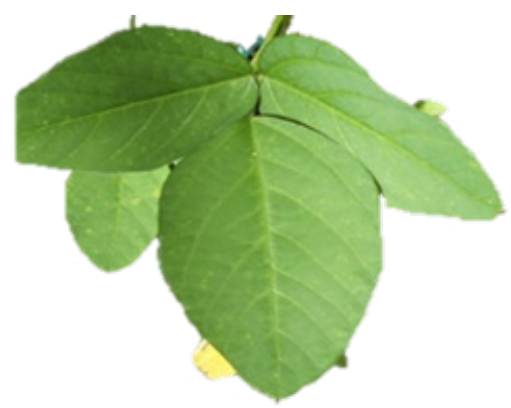

0

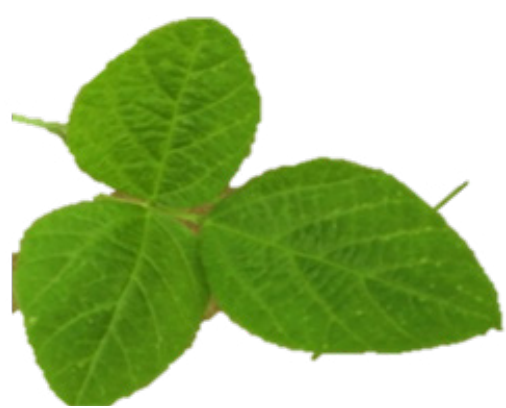

1

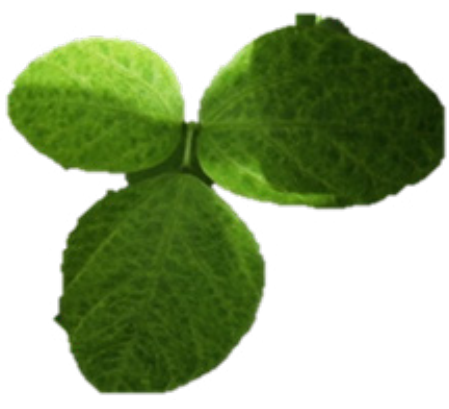

2

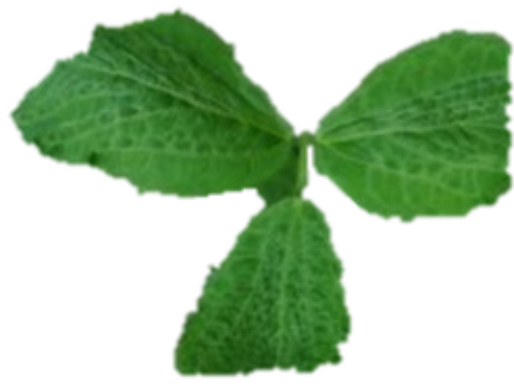

3

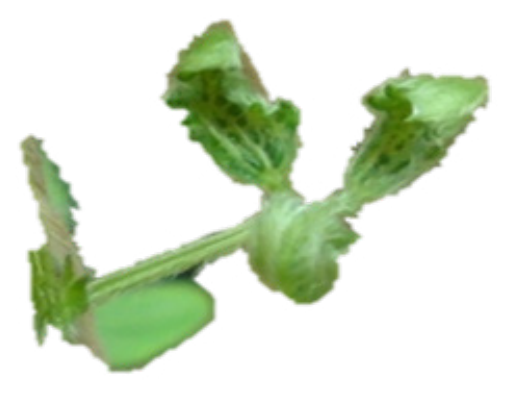

4

Gambar 1 Skor keparahan penyakit belang pada kedelai: 0, tidak bergejala; 1, tulang daun memucat dan daun melengkung ke bawah; 2 , belang dengan klorosis ringan pada tulang daun; 3 , belang dengan klorosis jelas pada tulang daun; dan 4, malformasi daun.

Tabel 1 Matriks skoring ketahanan varietas kedelai terhadap CPMMV berdasarkan periode inkubasi (HSI), insidensi penyakit (\%), dan keparahan penyakit (\%)

\begin{tabular}{lcc}
\hline Parameter & Kisaran nilai & Skor \\
\hline \multirow{3}{*}{ Periode inkubasi (HSI) } & $0-7$ & 4 \\
& $8-15$ & 3 \\
& $16-25$ & 2 \\
& $26-30$ & 1 \\
\hline \multirow{3}{*}{ Insidensi penyakit (\%) } & $0<25$ & 1 \\
& $25<50$ & 2 \\
& $50<75$ & 3 \\
Keparahan penyakit (\%) & $75<100$ & 4 \\
& $0<25$ & 1 \\
& $25<50$ & 2 \\
& $50<75$ & 3 \\
\hline
\end{tabular}

\section{Deteksi CPMMV}

Metode DIBA untuk mendeteksi CPMMV dilakukan mengikuti Mahmood et al. (1997). Daun sampel digerus dalam tris buffer saline (TBS: Tris- $\mathrm{HCl} 0.02 \mathrm{M}$ dan $\mathrm{NaCl} 0.15 \mathrm{M}$, $\mathrm{pH}$ 7.5) dengan perbandingan 1:10 (b/v). sebanyak $2 \mu \mathrm{L}$ cairan perasan tanaman tersebut diteteskan ke membran nitroselulosa (Hybond ${ }^{T M}-P$, Amersham Biosciences UK) dan dikeringanginkan.
Selanjutnya membran direndam di dalam $10 \mathrm{~mL}$ larutan blocking non fat milk $2 \%$ dalam TBS yang mengandung Triton X-100 dengan konsentrasi akhir 2\%. Membran kemudian diinkubasi pada suhu ruang sambil digoyang dengan kecepatan 50 rpm selama 2 jam menggunakan EYELA multi shaker MMS, dicuci sebanyak 5 kali dengan $\mathrm{dH} \mathrm{O}$, tiap pencucianberlangsung 5 menitsambildì goyang dengan kecepatan $100 \mathrm{rpm}$. Selanjutnya 
membran direndam dalam IgG-AP CPMMV (antiserum kedua CPMMV) (DSMZ, Jerman) dalam TBS yang mengandung $2 \%$ non fat milk dengan perbandingan 1:3000 (v/v), diinkubasi pada suhu $4{ }^{\circ} \mathrm{C}$ selama semalam. Membran kemudian dicuci sebanyak 5 kali dengan bufer TBS yang mengandung Tween $0.05 \%$ (TBST) dan dibilas dengan akuades. Selanjutnya, membran direndam selama 10-30 menit dalam $10 \mathrm{~mL}$ bufer substrat (Tris- $\mathrm{HCl} 0.1 \mathrm{M}, \mathrm{NaCl}$ $0.1 \mathrm{M}$, dan $\mathrm{MgCl} 5 \mathrm{mM}$ ) yang mengandung $45 \mu \mathrm{L}$ nitro blue têtrazolium (NBT) dan $35 \mu \mathrm{L}$ bromochloro indolil phosphate (BCIP). Reaksi positif ditandai dengan perubahan warna putih menjadi ungu pada membran nitroselulosa yang telah ditetesi cairan perasan tanaman dan reaksi dihentikan dengan akuades.

\section{HASIL}

\section{Kisaran Inang CPMMV}

Infeksi CPMMV pada tanaman indikator dari famili Leguminoceae dan Solanaceae menunjukkan gejala belang sistemik, klorosis tulang daun, dan malformasi daun; sedangkan pada famili Chenopodiaceae dan Amaranthaceae menyebabkan bercak klorosis lokal pada daun yang diinokulasi (Gambar 2). Hasil deteksi dengan metode DIBA menunjukkan bahwa semua tanaman dengan gejala sistemik memberikan reaksi positif terhadap antiserum CPMMV, kecuali A. hypogaea. Demikian pula, semua tanaman yang menunjukkan gejala klorosis lokal menunjukkan reaksi positif terhadap antiserum CPMMV (Tabel 2).

Hasil inokulasi balik dari tanaman indikator yang menunjukkan gejala sistemik dan positif terinfeksi CPMMV berhasil menularkan CPMMV ke tanaman kedelai sehat (Tabel 3). Penularan CPMMV ke tanaman kedelai menghasilkan insidensi penyakit 10-80\% dengan periode inkubasi 3-7 HSI. Dengan demikian, 8 spesies tanaman tersebut dapat menjadi inang CPMMV dan sekaligus sumber inokulum CPMMV untuk tanaman kedelai.

\section{Ketahanan Varietas Kedelai terhadap CPMMV}

Gejala infeksi CPMMV bervariasi bergantung pada varietas, antara lain belang ringan, belang parah, permukaan daun tidak rata dan mengerut, ukuran daun lebih kecil, serta perubahan bentuk daun (malformasi) (Tabel 4). Infeksi CPMMV terjadi pada semua varietas kedelai yang diuji walaupun dengan insidensi dan keparahan penyakit yang berbeda-beda. Insidensi penyakit paling rendah $(27.27 \%)$ terjadi pada varietas Argomulyo, sedangkan paling tinggi (100\%) ditunjukkan oleh varietas Detam 3 (Tabel 1). Periode inkubasi rata-rata yang ditunjukkan oleh varietas Detam 1, Detam 2', Detam 3, Detam 4, Anjasmoro, Wilis ialah 6-7 hari setelah inokulasi (HSI). Periode inkubasi pada varietas Malika, Argomulyo, Grobogan, dan Dena 1 menunjukkan waktu yang lebih panjang, yaitu 7-28 HSI.

Pengelompokan respons ketahanan varietas kedelai terhadap CPMMV didasarkan pada periode inkubasi, insidensi penyakit, dan keparahan penyakit yang disusun dalam matriks skoring. Berdasarkan skor ini kedelai yang dikelompokkan rentan ialah Detam 1, Detam 2, Detam 3, Anjasmoro, dan Wilis; moderat ialah Detam 4, Malika dan Dena 1; dan tahan ialah varietas (Argomulyo dan Grobogan).

\section{PEMBAHASAN}

Gejala infeksi CPMMV pada kedelai di Indonesia berupa belang, pemucatan tulang daun, dan daun menggulung. CPMMV isolat CR16 yang digunakan dalam penelitian ini mampu menimbulkan gejala belang sistemik pada tanaman Leguminoseae dan Solanaceae. Hal serupa telah dilaporkan sebelumnya (Pardina et al. 2004), walaupun dalam penelitian tersebut isolat CPMMV yang menginfeksi Solanaceae berbeda dengan isolat yang menginfeksi Leguminoseae. Chang et al. (2013) melaporkan isolat CPMMV Taiwan dapat menginfeksi tanaman Leguminoseae, 


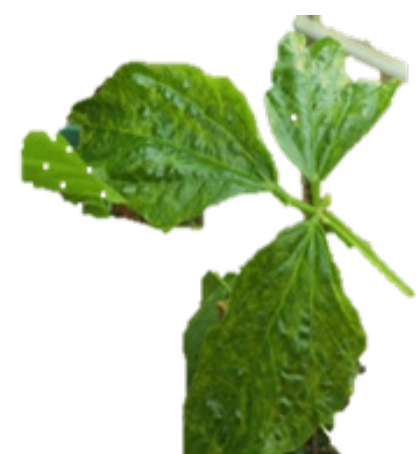

a

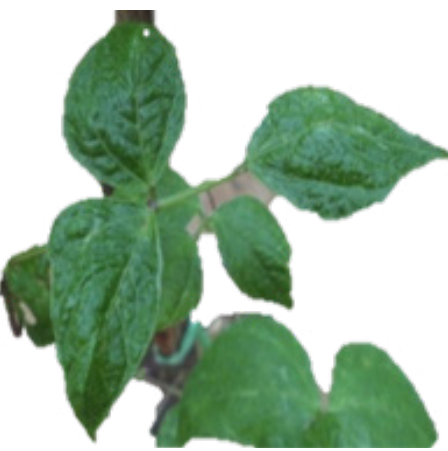

d

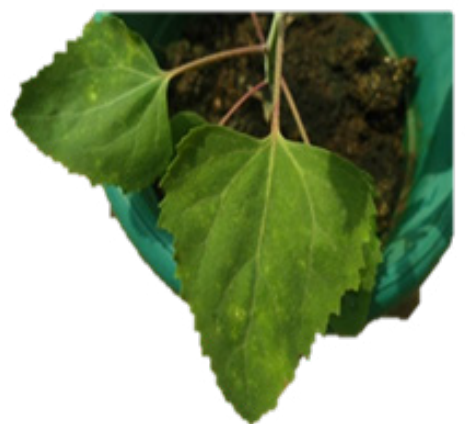

g

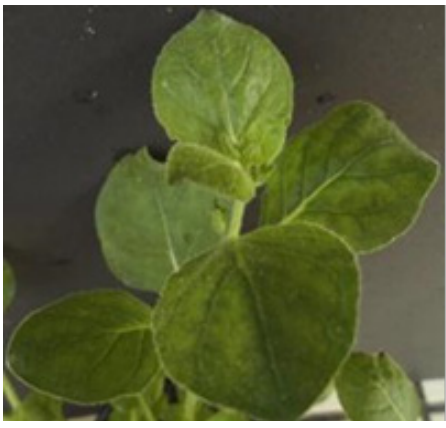

$\mathrm{j}$

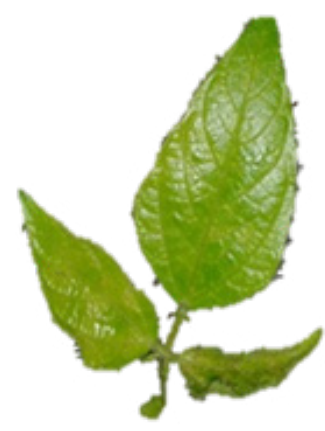

b

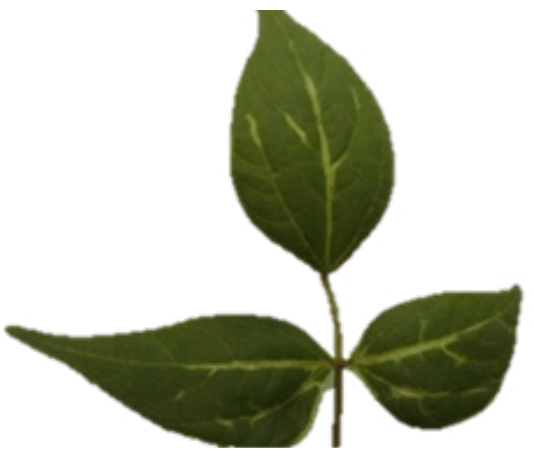

$\mathrm{e}$

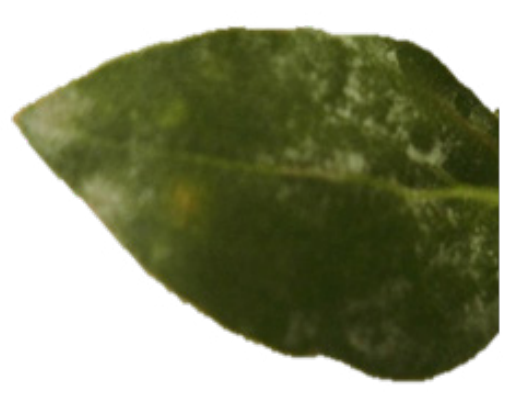

$\mathrm{h}$

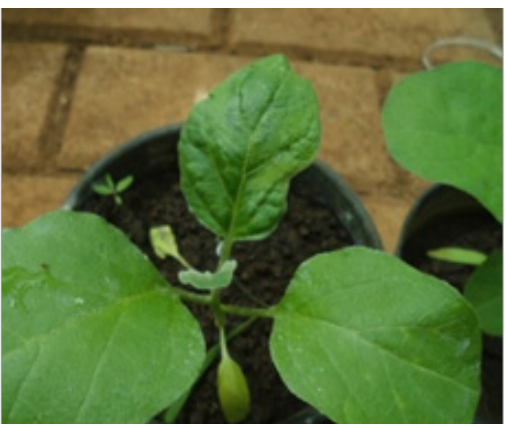

$\mathrm{k}$

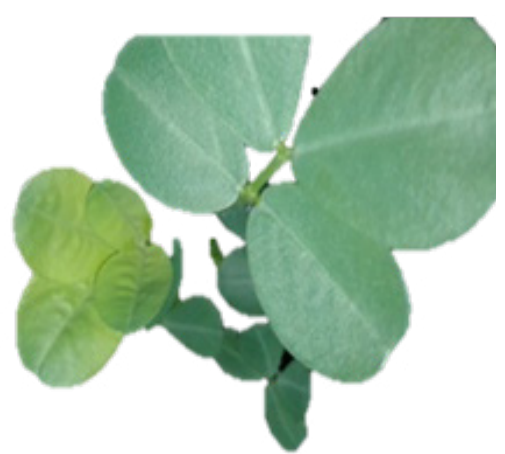

C

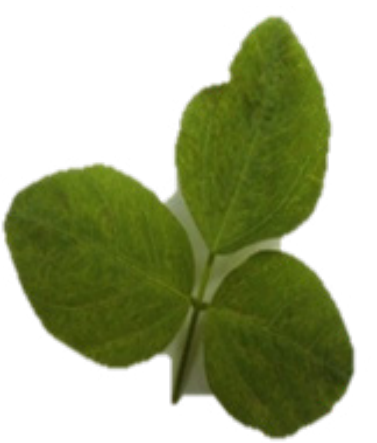

f

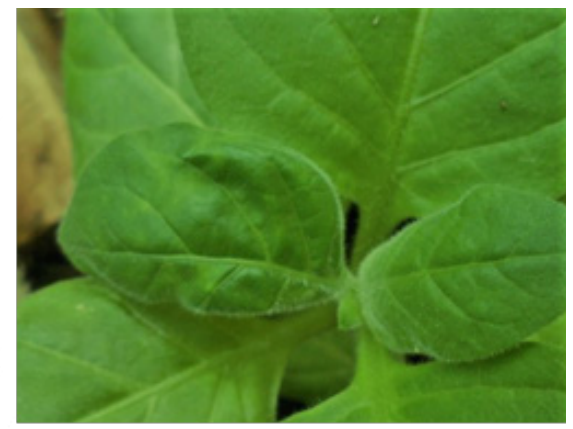

$\mathrm{i}$

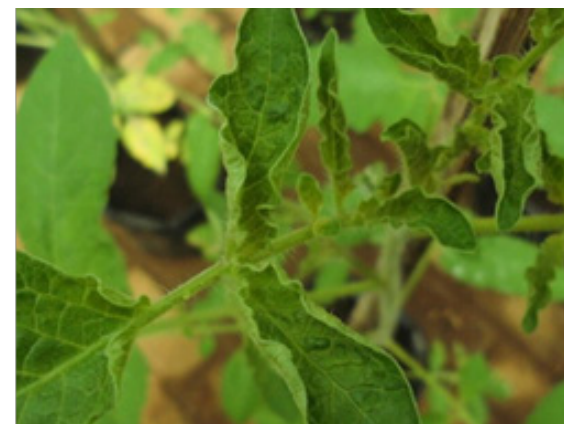

1

Gambar 2 Gejala infeksi CPMMV isolat CR16 pada tanaman indikator. a, daun melepuh dan belang sistemik pada Vigna unguiculta subsp. sesquipedalis; b, pemucatan tulang daun dan distorsi daun pada Vigna radiata; c, pemucatan sistemik pada pucuk Arachis hypogaea; d, belang sistemik dan permukaan daun tidak rata pada Phaseolus vulgaris; e, pemucatan tulang daun pada Phaseolus vulgaris; f, belang sistemik dan melepuh pada Glycine max; g, klorosis lokal pada Chenopodium amaranticolor; h, klorosis lokal pada Gomphrena globosa; i, belang sistemik dan malformasi daun pada Nicotiana tabacum; j, klorosis tulang daun dan belang sistemik pada $N$. benthamiana; $\mathrm{k}$, belang sistemik dan malformasi daun pada Lycopersicum melongena; 1 , belang sistemik dan malformasi daun pada L. esculentum. 
Tabel 2 Gejala CPMMV isolat CR16 pada beberapa tanaman indikator

\begin{tabular}{|c|c|c|c|c|}
\hline Tanaman indikator & Gejala & $\begin{array}{c}\text { Jumlah tanaman } \\
\text { bergejala (jumlah } \\
\text { total tanaman)* }\end{array}$ & $\begin{array}{c}\text { Periode } \\
\text { Inkubasi } \\
\text { (HSI) }\end{array}$ & $\begin{array}{c}\text { Jumlah sampel } \\
\text { terinfeksi } \\
\text { CPMMV ** }\end{array}$ \\
\hline \multicolumn{5}{|l|}{ Leguminoceae } \\
\hline Vigna unguiculata & $\begin{array}{l}\text { Belang sistemik, } \\
\text { malformasi daun }\end{array}$ & $10(10)$ & 33 & 9 \\
\hline Vigna radiata & Klorosis tulang daun & $1(10)$ & 7 & 1 \\
\hline Arachis hypogaea & Klorosis tulang daun & $1(10)$ & 7 & 0 \\
\hline Phaseolus vulgaris & $\begin{array}{l}\text { Belang, tulang daun } \\
\text { memutih }\end{array}$ & $4(10)$ & 5 & 4 \\
\hline Glycine max & $\begin{array}{l}\text { Belang sistemik, } \\
\text { daun melepuh }\end{array}$ & $8(10)$ & 7 & 8 \\
\hline \multicolumn{5}{|l|}{ Amaranthaceae } \\
\hline Chenopodium amaranticolor & Lesio local & $1(10)$ & 10 & 1 \\
\hline Gomphrena globosa & Lesio local & $1(10)$ & 7 & 1 \\
\hline \multicolumn{5}{|l|}{ Solanaceae } \\
\hline Nicotiana tabacum & $\begin{array}{l}\text { Belang sistemik, } \\
\text { malformasi daun }\end{array}$ & $7(10)$ & 7 & 7 \\
\hline Nicotiana benthamiana & Klorosis tulang daun & $2(2)$ & 14 & 2 \\
\hline Lycopersicum melongena & $\begin{array}{l}\text { Belang sistemik, } \\
\text { malformasi daun }\end{array}$ & $7(10)$ & 8 & 7 \\
\hline Lycopersicum esculentum & $\begin{array}{l}\text { Belang sistemik, } \\
\text { malformasi daun }\end{array}$ & $8(10)$ & 8 & 8 \\
\hline
\end{tabular}

Tabel 3 Inokulasi balik CPMMV dari tanaman indikator ke tanaman kedelai

\begin{tabular}{lcccc}
\hline $\begin{array}{l}\text { Tanaman indikator sebagai } \\
\text { sumber inokulum }\end{array}$ & $\begin{array}{c}\text { Gejala pada } \\
\text { kedelai }\end{array}$ & $\begin{array}{c}\text { Jumlah } \\
\text { tanaman } \\
\text { bergejala* }\end{array}$ & $\begin{array}{c}\text { Periode inkubasi } \\
\text { (HSI) }\end{array}$ & $\begin{array}{c}\text { Jumlah sampel } \\
\text { terinfeksi } \\
\text { CPMMV ** }\end{array}$ \\
\hline Vigna unguiculata & belang sistemik & 2 & 3 & 2 \\
Vigna radiata & belang sistemik & 1 & 6 & 1 \\
Phaseolus vulgaris & belang sistemik & 4 & 6 & 4 \\
Glycine max & belang sistemik & 8 & 7 & 8 \\
Nicotiana tabacum & belang sistemik & 4 & 7 & 4 \\
Solanum melongena & belang sistemik & 5 & 7 & 5 \\
Lycopersicum esculentum & belang sistemik & 2 & 7 & 2 \\
\hline
\end{tabular}

*Jumlah tanaman uji untuk masing-masing tanaman indikator adalah 10 tanaman, kecuali $N$. benthamiana dan L.melongena 8 tanaman, L. esculentum 7 tanaman;

**Konfirmasi infeksi CPMMV dilakukan dengan metode DIBA.

namun tidak menginfeksi Cucurbitaceae dan Solanaceae. Infeksi CPMMV isolat CR16 pada kacang panjang ( $V$. unguiculata) menunjukkan gejala belang sistemik, pemucatan tulang daun, lamina daun berkerut, dan malformasi daun. Sedangkan Yadav (2013) melaporkan bahwa infeksi CPMMV pada kacang panjang di India menunjukkan gejala lesio klorosis yang berkembang menjadi bercak nekrosis dengan belang lemah dan daun menggulung. Respons tanaman kacang buncis (P. vulgaris) terhadap CPMMV isolat CR16 menunjukkan hasil yang sama dengan penelitian Yadav (2013), yaitu gejala belang, klorosis pada tulang daun, dan daun keriting. Yadav (2013) melaporkan bahwa infeksi CPMMV pada $N$. tabacum tidak menunjukkan gejala, tetapi infeksi CPMMV isolat CR16 menyebabkan belang, pemucatan 
Tabel 4 Pengelompokkan respons varietas kedelai terhadap CPMMV isolat CR16

\begin{tabular}{lcccccc}
\hline Varietas & $\begin{array}{c}\text { Periode } \\
\text { inkubasi } \\
(\mathrm{HSI})\end{array}$ & Gejala awal* & $\begin{array}{c}\text { Insidensi } \\
\text { penyakit } \\
(\%)\end{array}$ & $\begin{array}{c}\text { Keparahan } \\
\text { penyakit } \\
(\%)\end{array}$ & Total nilai & Respons \\
\hline 'Detam1' & $6-7$ & $\mathrm{BR}$ & 75.00 & 57.5 & 11 & Rentan \\
'Detam2' & $6-7$ & $\mathrm{BR}$ & 72.73 & 55.0 & 10 & Rentan \\
'Detam3' & $6-7$ & $\mathrm{BR}$ & 100.00 & 57.5 & 11 & Rentan \\
'Detam4' & $6-7$ & $\mathrm{BR}$ & 55.56 & 27.5 & 9 & Moderat \\
'Malika' & $6-28$ & $\mathrm{BP}, \mathrm{DM}, \mathrm{DD}$ & 50.00 & 52.5 & 7 & Moderat \\
'Anjasmoro' & $6-7$ & $\mathrm{BP}, \mathrm{DM}, \mathrm{DD}$ & 57.14 & 75.0 & 11 & Rentan \\
'Wilis' & $6-7$ & $\mathrm{BP}$ & 70.00 & 70.0 & 10 & Rentan \\
'Argomulyo' & $6-28$ & $\mathrm{BR}$ & 27.27 & 22.5 & 4 & Tahan \\
'Grobogan' & $7-28$ & $\mathrm{BR}$ & 33.33 & 12.5 & 4 & Tahan \\
'Dena1' & $7-22$ & $\mathrm{BR}$ & 62.50 & 37.5 & 7 & Moderat \\
\hline
\end{tabular}

*BR, belang ringan; BP, belang parah; DM, daun mengerut; DD, distorsi daun.

tulang daun dan malformasi. Perbedaan kisaran inang dan respons tanaman indikator terhadap isolat CPMMV yang berbeda dapat disebabkan oleh perbedaan galur virus.

Uji inokulasi balik CPMMV dari tanaman indikator (Leguminoseae dan Solanaceae) ke tanaman kedelai menunjukkan potensi tanaman indikator sebagai sumber inokulum CPMMV bagi tanaman kedelai. Begitu pula sebaliknya, isolat CPMMV dari tanaman kedelai dapat menjadi inokulum bagi tanaman Leguminoseae dan Solanaceae lainnya. Dengan demikian insidensi penyakit belang akan cepat meningkat apabila tanaman dari kelompok Leguminoceae atau Solanaceae ditanam secara tumpang sari atau di lahan yang berdampingan dengan tanaman kedelai.

CPMMV isolat CR16 mempunyai kisaran inang yang berbeda dibandingkan dengan isolat CPMMV yang dilaporkan sebelumnya, yaitu isolat dari Taiwan dan India. Isolat CPMMV di Taiwan menginfeksi Leguminoceae, tetapi tidak menginfeksi Solanaceae (Chang et al. 2013). Pengujian kisaran inang CPMMV India menunjukkan bahwa CPMMV tidak menimbulkan gejala pada $N$. tabacum (Yadav et al. 2013). Namun, dalam penelitian ini terbukti isolat CPMMV CR16 dari tanaman kedelai mampu menginfeksi L. esculentum, $S$. melongena, dan N. tabacum. Tanaman inang CPMMV CR16 cukup luas dan berpotensi menjadi sumber infeksi untuk tanaman kedelai. Oleh karena itu, penanaman kedelai disarankan tidak bersamaan dengan tanaman Leguminoseae dan Solanaceae karena berpotensi saling menularkan CPMMV.

Pengujian respons ketahanan sepuluh varietas kedelai menunjukkan sebagian besar varietas kedelai moderat dan rentan terhadap infeksi CPMMV isolat CR16. Dua varietas yang rentan terhadap CPMMV, 'Anjasmoro' dan 'Wilis', merupakan yang paling banyak ditanam di Indonesia. Varietas 'Anjasmoro' paling banyak ditanam di Nusa Tenggara Barat, Nangro Aceh Darusssalam, dan Jawa Barat; sedangkan varietas 'Wilis' dan 'Argomulyo' mendominasi lahan kedelai di Jawa Timur (Krisdiana 2014). Varietas Grobogan merupakan kedelai yang tahan terhadap CPMMV dan paling banyak ditanam di Jawa Tengah. Penyakit belang CPMMV berpotensi menjadi penyakit yang endemik di sentra budi daya kedelai di Indonesia karena varietas yang paling banyak ditanam merupakan varietas rentan dan moderat terhadap CPMMV.

\section{UCAPAN TERIMA KASIH}

Penulis mengucapkan terimakasih atas bantuan dana Penelitian Disertasi Doktor kepada Direktorat Riset dan Pengabdian Masyarakat Direktorat Jenderal Penguatan Riset dan Pengembangan Kementerian Riset, Teknologi, dan Pendidikan Tinggi 
sesuai dengan Surat Perjanjian Penugasan Pelaksanaan Program Penelitian Batch I, nomor: 044/SP2H/LT/DRPM/II/2016, tanggal 17 Februari 2016.

\section{DAFTAR PUSTAKA}

Akin HM. 2003. Respon beberapa genotipe kedelai terhadap infeksi cowpea mild mottle virus. J HPT Trop. 3(2):40-43.

Brito M, Fernandez-Rodriguez T, Garrido MJ, Mejias A, Romano M, Marys E. 2012. First report of Cowpea mild mottle Carlavirus on yardlong bean (Vigna unguiculata subsp. sesquipedalis) in Venezuela. Viruses. 4(12):3804-11. DOI: http://dx.doi.org/10.3390/v4123804.

Chang C, Chien L, Tsai C, Lin Y, Cheng Y. 2013. First report of Cowpea mild mottle virus in cowpea and French bean in Taiwan. Plant Dis. 97(7):1001. DOI://doi. org/10.1094/PDIS-10-12-0935-PND.

Clark MF, Adams A. 1977. Characteristics of the microplate method of enzyme-linked immunosorbent assay for the detection of plant viruses. J Gen Virol. 34(3):475-483.

Iwaki M, Thongmeearkom P, Honda Y, Prommin M, Deema N, Hibi T, Iizuka N, Ong C, Saleh N. 1986. Cowpea mild mottle virus occurring on soybean and peanut in southeast Asian countries. Trop Agric Res Centre Tech. Bull. 21:106-120.

Jeyanandarajah P, Brunt AA. 1993. The natural occurrence, transmission, properties and possible affinities of cowpea mild mottle virus. J Phytopathol. 137(2):148-156. DOI: http://dx.doi. org/10.1111/j.1439-0434.1993.tb01334.x.

Krisdiana R. 2014. Penyebaran varietas unggul kedelai dan dampaknya terhadap ekonomi perdesaan. J Pen Pert Tan Pangan. 33(1):61-69.

Mahmood T, Hein GL, French RC. 1997. Development of serological procedures for rapid and reliable detection of Wheat streak mosaic virus in a single wheat curl mite. Plant Dis. 81(3):250-253. DOI: https:// doi.org/10.1094/PDIS.1997.81.3.250.

Mansour A, Al-Musa A, Vetten H, Lesemann DE. 1998. Properties of a Cowpea mild mottle virus (CPMMV) isolate from eggplant in Jordan and evidence for biological and serological differences between CPMMV isolates from leguminons and solanaceous hosts. J Phytopathol. 146(11-12):539-547. DOI: http://dx.doi.org/10.1111/1439-0434. ep6401455.

Pardina PER, Arneodo J, Truol G, Herrera P, Laguna IG. 2004. First report of Cowpea mild mottle virus in bean crops in Argentina. Australas. Plant Pathol. 33(1):129-130. DOI: http://dx.doi. org/10.1590/S010041582006000300015.

Yadav MK, Biswas KK, Lal SK, Baranwal VK, Jain RK. 2013. A distinct strain of cowpea mild mottle virus infecting soybean in India. J Phytopathol. 161(10):739-744. DOI: http://dx.doi.org/10.1111/jph.12119. 